\title{
Effect of relaxin on parturition and frequency of live births in pigs*
}

\author{
B. S. Nara, F. A. Welk, J. E. Rutherford $\dagger$, O. D. Sherwood $\dagger$ \\ and N. L. First
}

Department of Meat and Animal Science, University of Wisconsin-Madison, WI 53706 and $\uparrow$ School of Basic Medical Sciences and Department of Physiology and Biophysics, University of Illinois, Urbana, IL 61801, U.S.A.

\begin{abstract}
Summary. Gilts on Day 105 of gestation were sham ovariectomized (Group C, N = 5); ovariectomized and given i.m. injections of $100 \mathrm{mg}$ progesterone twice daily from Day 105 to 112 (Group OP, $N=5$ ); or ovariectomized and given progesterone and i.m. injections of $1 \mathrm{mg}$ highly purified porcine relaxin 4 times/day from Day 105 until the end of parturition (Group OPR, $N=5$ ). Concentrations of progesterone in peripheral plasma of gilts in Group OP were similar to those in Group C. Relaxin was undetectable in peripheral plasma of gilts in Group OP which also showed prolonged parturition $(P<0.001)$ and impaired frequency of live births $(P<0.001)$, although onset of lactation was not affected. In Group OPR the duration of parturition and frequency of live births were similar to those observed for gilts in Group $\mathrm{C}$. These results indicate that the ovarian hormone relaxin is necessary for normal duration of parturition and frequency of live births and that the onset of lactation is not prevented by an absence of relaxin.
\end{abstract}

\section{Introduction}

A high frequency of live births in pigs is obtained when expulsion of the fetuses during parturition occurs rapidly and in quick succession (Friend, Cunningham \& Nicholson, 1962; MacDonald, Holmes \& Moxley, 1963; Randall, 1972). Passage of piglets through the birth canal is facilitated by increased myometrial contractions (Sprecher, Leman, Dziuk, Cropper \& DeDecker, 1974) and by increased dilatation of the uterine cervix during parturition (Kertiles \& Anderson, 1979).

Relaxin has been shown to cause dilatation of the uterine cervix in ovariectomized non-pregnant gilts (Zarrow, Neher, Sikes, Brennan \& Bullard, 1956) and premature cervical dilatation and shortening of the duration of parturition in pregnant gilts (Kertiles \& Anderson, 1979). The main source of relaxin in pregnant pigs is the corpora lutea and ovariectomy of gilts on Day 108 of gestation results in a high incidence of stillbirths and very low levels of relaxin after the ovariectomy (Nara, Darmadja \& First, 1981).

The present study was conducted to determine whether relaxin is necessary for a rapid parturition and the birth of live piglets.

* Reprint requests to: Dr N. L. First, Department of Meat \& Animal Science, University of Wisconsin, Madison, Wisconsin 53706, U.S.A. 


\section{Materials and Methods}

\section{Experimental animals}

Primigravid Yorkshire gilts 10-12 months of age and weighing $180-240 \mathrm{~kg}$ on Day 105 of gestation were used. The day of mating was designated Day 0 of pregnancy.

On Day 105 of gestation at 08:00-12:00 h gilts were anaesthetized by i.v. infusion of a $4 \%$ sodium thiamylal solution (Surital, Parke Davis). Anaesthesia was maintained on a closed-circuit system of $1.5-4.0 \%$ halothane (Ayerst Laboratories), nitrous oxide $(400 \mathrm{ml} / \mathrm{min}$ ) and oxygen $(800 \mathrm{ml} / \mathrm{min})$ as described by Dziuk, Phillips \& Graber (1964). Aseptic surgical techniques were used and gilts were bilaterally ovariectomized through lumbar incisions or sham operated. In sham ovariectomy, both ovaries were exteriorized, manipulated and then returned to the body cavity.

\section{Treatments}

Fifteen gilts were assigned randomly to one of 3 treatments. In Group $\mathrm{C}$ gilts were sham ovariectomized and received i.m. injections of (1) $4 \mathrm{ml}$ corn oil at 12-h intervals from 18:00 h on Day 105 until 18:00 h on Day 112 of gestation and (2) $1 \mathrm{ml}$ saline $(9 \mathrm{~g} \mathrm{NaCl} / \mathrm{l})$ at 6 -h intervals from 12:00 h on Day 105 of gestation until parturition was completed. In Group OP ovariectomy was followed by i.m. injections of (1) $100 \mathrm{mg}$ progesterone in $4 \mathrm{ml}$ corn oil and (2) $1 \mathrm{ml}$ saline according to the injection regimen used in Group $\mathrm{C}$ for corn oil and saline. In Group OPR gilts were ovariectomized and treated with progesterone as for Group OP, but instead of the saline injections $1 \mathrm{mg}$ highly purified porcine relaxin (Sherwood \& O'Byrne, 1974) in $1 \mathrm{ml}$ of saline was injected. Thus, each gilt in this treatment received $4 \mathrm{mg}$ relaxin per day.

\section{Dose determinations of relaxin and progesterone}

From the disappearance curve of relaxin immunoactivity following intravenous injection of relaxin (Sherwood, Crnekovic, Gordon \& Rutherford, 1980) it was calculated that, for a gilt weighing $160 \mathrm{~kg}$, an i.v. injection of $1 \mathrm{mg}$ relaxin would give a peripheral plasma concentration of relaxin of $5 \mathrm{ng} / \mathrm{ml}$ or more for at least $4 \mathrm{~h}$ following each injection. Feasibility of this dose of relaxin for i.m. injections into pregnant pigs was tested in a preliminary trial using 2 gilts (185 and $200 \mathrm{~kg}$ ) that were given Treatment OPR. Treatment in one gilt started on Day 100 and in the other on Day 107 of gestation. At the beginning, middle and near the end of the relaxin treatment, blood was collected just before an injection of relaxin and then at 5 min and 1,2,3,4, 5 and $6 \mathrm{~h}$ after the injection. Relaxin data between gilts were pooled within time of sampling, since within times of sampling they were not significantly different between gilts. Means \pm s.e.m. of relaxin concentrations of the 6 samples for each time interval are shown in Table 1. These results show that $1 \mathrm{mg}$ relaxin given every $6 \mathrm{~h}$ by i.m. injection maintained mean relaxin concentrations above $5 \mathrm{ng} / \mathrm{ml}$ for $6 \mathrm{~h}$.

Table 1. Mean + s.e.m. relaxin concentrations in plasma collected from 2 gilts at the beginning, middle and near the end of treatment with relaxin

\begin{tabular}{|c|c|c|c|c|c|c|c|c|}
\hline & \multicolumn{8}{|c|}{ Time from injection of relaxin } \\
\hline & 0 & $5 \mathrm{~min}$ & $1 \mathrm{~h}$ & $2 \mathrm{~h}$ & $3 \mathrm{~h}$ & $4 \mathrm{~h}$ & $5 \mathrm{~h}$ & $6 \mathrm{~h}$ \\
\hline Relaxin (ng/ml) & $\begin{aligned} & 5.5^{\mathrm{a}} \\
\pm & 0.8\end{aligned}$ & $\begin{array}{c}10.4^{\mathrm{bc}} \\
\pm 1.0\end{array}$ & $\begin{array}{c}23.7^{\mathrm{d}} \\
\pm 1.8\end{array}$ & $\begin{array}{c}28.4^{\mathrm{d}} \\
\pm 7.7\end{array}$ & $\begin{array}{c}17.9^{\text {cd }} \\
\pm \\
\pm .9\end{array}$ & $\begin{array}{c}10 \cdot 8^{\mathrm{bc}} \\
\pm 1.7\end{array}$ & $\begin{aligned} & 8.7^{\mathrm{ab}} \\
\pm & 1.4\end{aligned}$ & $\begin{array}{r}6.3^{\mathrm{a}} \\
+1.3\end{array}$ \\
\hline
\end{tabular}

Means bearing different superscripts are different $(P<0.05)$. Data transformed to $\log \mathrm{X}$ before analysis. 
The dose of $100 \mathrm{mg}$ progesterone was also tested by using the 2 gilts in the preliminary trial. At the beginning, middle and near the end of the progesterone treatment, blood was collected just before an injection of progesterone and then at $5 \mathrm{~min}$ and 3,6,9 and $12 \mathrm{~h}$ after the injection. Progesterone data between gilts were pooled within time of sampling, since within times of sampling they were not significantly different between gilts. Means \pm s.e.m. of progesterone concentrations of the 6 samples for each time interval are shown in Table 2; values were maintained at levels comparable to those in intact controls (see Text-figure 1).

Table 2. Mean \pm s.e.m. progesterone concentrations in plasma collected from 2 gilts at the beginning, middle and near the end of treatment with progesterone

\begin{tabular}{ccccccc}
\hline & \multicolumn{5}{c}{ Time from injection of progesterone } \\
\cline { 2 - 6 } & 0 & $5 \mathrm{~min}$ & $3 \mathrm{~h}$ & $6 \mathrm{~h}$ & $9 \mathrm{~h}$ & $12 \mathrm{~h}$ \\
\hline Progesterone $(\mathrm{ng} / \mathrm{mi})$ & $14 \cdot 1 \pm 2 \cdot 1^{\mathrm{a}}$ & $20 \cdot 9 \pm 2 \cdot 0^{\mathrm{a}}$ & $20 \cdot 4 \pm 2 \cdot 5^{\mathrm{a}}$ & $23 \cdot 3 \pm 2 \cdot 8^{\mathrm{a}}$ & $20 \cdot 2 \pm 3 \cdot 3^{\mathrm{a}}$ & $17 \cdot 3 \pm 2 \cdot 9^{\mathrm{a}}$ \\
\hline
\end{tabular}

Means bearing same superscript are not different $(P>0.05)$.

\section{Observations}

Onset of lactation was determined by manual ejection of milk from the teats at times of saline or relaxin injections. After milk could be ejected, gilts were put in farrowing crates and observed for onset and end of farrowing using a videotape recording technique to determine duration of parturition (Nara \& First, 1981b), i.e. the interval between the appearance of the first to the expulsion of the last piglet. Stillbirths were determined by the lung flotation test (Nara \& First, 1981b): dead fetuses with lung tissue that floated were considered live born.

\section{Plasma samples}

Blood samples were taken before surgery on Day 105 of gestation and daily thereafter at 09:00 $\mathrm{h}$ until 1 day post partum. Blood was obtained by venepuncture of the anterior vena cava and collected into heparinized centrifuge tubes and immediately centrifuged at $1500 \mathrm{~g}$ for 15 min. Plasma was removed and stored in $4 \mathrm{ml}$ aliquots at $-20^{\circ} \mathrm{C}$ until assayed for progesterone and relaxin.

\section{Radioimmunoassay procedures}

Progesterone was measured in duplicate samples by the radioimmunoassay method described by Nara \& First (1981b). The antiserum, raised in rabbits against progesterone$11 \alpha$-BSA, was donated by R. B. Staigmiller. Specificity of the antiserum has been determined and reported by Staigmiller, Short, Bellows \& Carr (1979). Specificity was confirmed when no differences in progesterone content were found in plasma samples obtained from pigs near parturition (Nara \& First, 1981b) regardless of whether the progesterone radioimmunoassays were made with hexane extracts or the progesterone-containing fraction following chromatography of hexane extracts on Sephadex LH-20. Hence, progesterone was measured after extraction of $1 \mathrm{ml}$ aliquots of plasma with $5 \mathrm{ml}$ hexane without further chromatographic purification. The inter- and intra-assay coefficients of variation for a sample with a mean concentration of $8.52 \mathrm{ng}$ progesterone/ml were 11.6 and $9.8 \%$, respectively. The least detectable dose was $150 \mathrm{pg} / \mathrm{ml}$.

Relaxin concentrations were determined by radioimmunoassay (Sherwood, Rosentreter \& Birkhimer, 1975) employing multiple volumes ( 2 or 3 ) of each unknown plasma sample. Relaxin 
standards and plasma unknowns were assayed in quadruplicate. Logit and log transformations (Rodbard \& Lewald, 1970) of the porcine relaxin standard curve were used to obtain a linear dose-response curve. The least detectable dose was $32 \mathrm{pg} / \mathrm{ml}$. The intra- and inter-assay coefficients of variation were 11.4 and $8 \cdot 1 \%$ respectively.

\section{Statistical procedures}

Data on length of gestation, duration of parturition and percentage of live births were assessed by analysis of variance. An orthogonal set of single degree of freedom comparisons among treatments: (1) Group C + Group OPR versus $2 \times$ Group OP and (2) Group C versus Group OPR was planned and tested for significant effects. To remove heterogeneity of variance, data on duration of parturition were transformed into $\log \mathrm{X}$ values and percentage data into arcsin values before analysis (Steele \& Torrie, 1960). Differences in litter size among treatments and differences in concentrations of progesterone and relaxin among days within treatments were determined by analysis of variance and Duncan's multiple range test (Steele \& Torrie, 1960).

\section{Results}

As shown in Table 3, length of gestation was not different among treatments. Duration of parturition was greatly prolonged $(P<0.001)$ and the incidence of stillbirths was increased $(P<0.001)$ in Group OP gilts. In Group OPR, however, the duration of parturition and the incidence of stillbirths were similar to those for Group $C$. There was no difference in litter size among the treatment groups. All except 2 gilts exhibited onset of lactation within $12 \mathrm{~h}$ before farrowing.

Table 3. Mean \pm s.e.m. values for various characteristics of gilts in Group C (control), Group OP (ovariectomized + progesterone) and Group OPR (ovariectomized + progesterone + relaxin)

\begin{tabular}{lccc}
\hline & $\begin{array}{c}\text { Group C } \\
(\mathrm{N}=5)\end{array}$ & $\begin{array}{c}\text { Group OP } \\
(\mathrm{N}=5)\end{array}$ & $\begin{array}{c}\text { Group OPR } \\
(\mathrm{N}=5)\end{array}$ \\
\hline Length of gestation (days) & $114 \cdot 6 \pm 0 \cdot 5^{\mathrm{a}}$ & $115 \cdot 2 \pm 0 \cdot 2^{\mathrm{a}}$ & $115 \cdot 0 \pm 0^{\mathrm{a}}$ \\
Duration of parturition (h) & $4 \cdot 0 \pm 0 \cdot 5^{\mathrm{a}}$ & $18 \cdot 4 \pm 2 \cdot 3^{\mathrm{b}}$ & $3 \cdot 6 \pm 0 \cdot 7^{\mathrm{a}}$ \\
Litter size & $10 \cdot 2 \pm 1 \cdot 3^{\mathrm{a}}$ & $11 \cdot 8 \pm 1 \cdot 0^{\mathrm{a}}$ & $11 \cdot 6 \pm 1 \cdot 1^{\mathrm{a}}$ \\
Percentage of live births* & $94 \cdot 6 \pm 2 \cdot 3$ & $43 \cdot 9 \pm 6 \cdot 0^{\mathrm{b}}$ & $94 \cdot 1 \pm 3 \cdot 6^{\mathrm{a}}$ \\
Onset of lactation $\dagger$ & $5 / 5$ & $4 / 5$ & $4 / 5$ \\
\hline
\end{tabular}

Means in same row bearing different superscripts are different $(P<0.001)$.

* $\frac{\text { No. of piglets born alive/litter }}{\text { Total no. of piglets born/litter }} \times 100$.

+ Proportion of gilts in each group showing onset of lactation within $12 \mathrm{~h}$ pre partum. The value for the 5 th gilt in Group OP was $15 \mathrm{~h}$ and in Group OPR, $81 \mathrm{~h}$.

Progesterone and relaxin concentrations are shown in Text-fig. 1. Before surgery, plasma concentrations of progesterone varied from 11 to $23 \mathrm{ng} / \mathrm{ml}$ and relaxin concentrations from 0.3 to $13.6 \mathrm{ng} / \mathrm{ml}$ in gilts in all groups. Progesterone levels were maintained at $>7 \mathrm{ng} / \mathrm{ml}$ in all 3 groups until the day before parturition. In Group $\mathrm{C}$ relaxin concentrations started to increase on approximately Day 109 of gestation and reached peak levels within $48 \mathrm{~h}$ before parturition. In Group OP relaxin concentrations decreased to non-detectable levels by 1 day after ovariectomy. In Group OPR plasma concentrations of relaxin were maintained at levels between 6 and 16 $\mathrm{ng} / \mathrm{ml}$. 


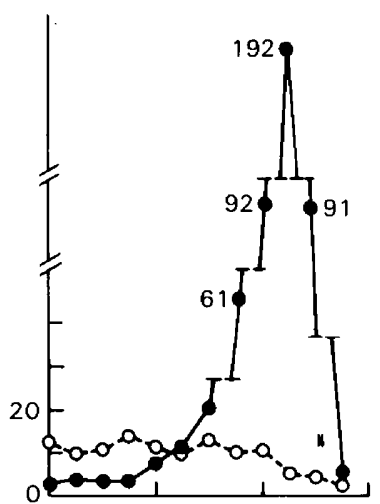

(a) GROUP C
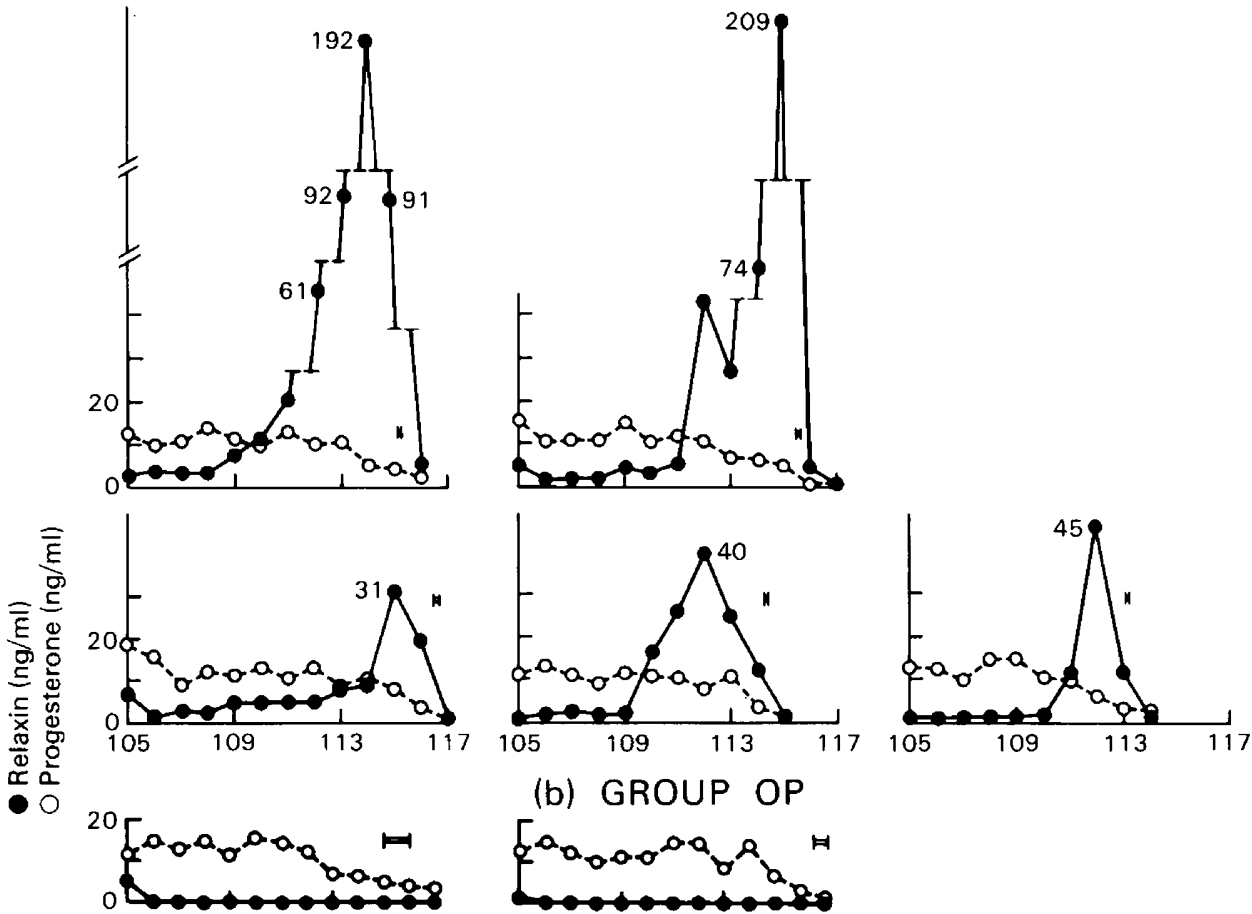

(b) GROUP OP
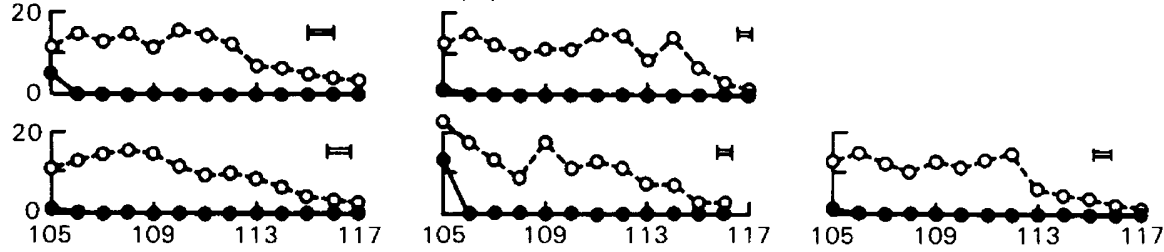

(c) GROUP OPR
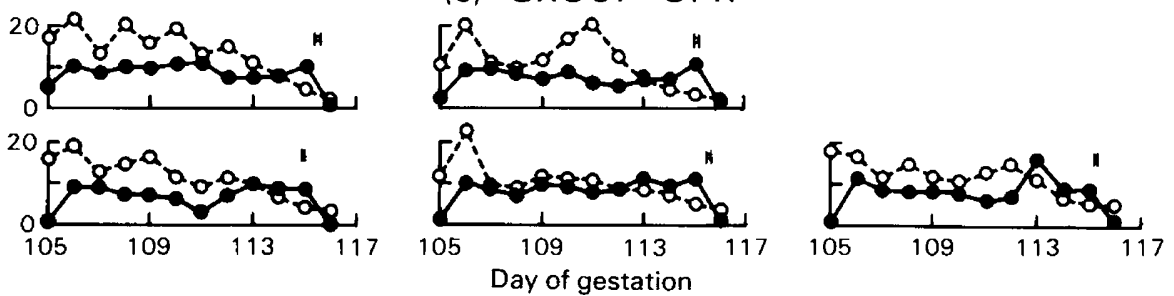

Text-fig. 1. Daily concentrations of progesterone and relaxin in peripheral plasma of individual gilts in (a) Group C, (b) Group OP and (c) Group OPR from before operation on Day 105 of gestation until the day after parturition. Duration of parturition for each gilt is indicated by an open bar.

\section{Discussion}

The results of the present experiment indicate that the ovarian hormone relaxin is necessary for a normal duration of parturition and frequency of live births. (1) The apparent absence of relaxin in peripheral blood of ovariectomized gilts treated with only progesterone for 10 days before farrowing was associated with prolonged parturition and a high incidence of stillbirths. (2) Injections of relaxin at 6-h intervals to gilts that were ovariectomized and treated with progesterone throughout the 10 days pre partum resulted in the normal rapid delivery of live piglets. 
The prolonged lack of relaxin in gilts of Group OP may have caused insufficient dilatation of the cervix at parturition, which resulted in dystocia, prolonged parturition and high frequency of stillbirths. Relaxin causes dilatation of the cervix in pregnant pigs (Kertiles \& Anderson, 1979): i.m. injections of partly purified porcine relaxin caused premature dilatation of the uterine cervix in pregnant gilts and removal of the corpora lutea on Day 110 of gestation resulted in premature deliveries that were of shorter duration than those of similarly operated gilts that were not pretreated with relaxin. The longer duration of parturition in the latter group of gilts was, however, not significantly prolonged when compared to those of intact controls farrowing at term and the frequency of live births was not significantly different among treatment groups (Kertiles \& Anderson, 1979). Unlike the gilts of Group OP, however, gilts without CL had not suffered a prolonged lack of relaxin, because their pregnancies were terminated within $36 \mathrm{~h}$ after operation. This may be why CL removal did not impair parturition (Kertiles \& Anderson, 1979). Moreover, blood relaxin levels at Day 110 of gestation are about $2.7 \mathrm{ng} / \mathrm{ml}$ (Sherwood, Nara, Welk, First \& Rutherford, 1981).

It has previously been demonstrated that the onset of lactation occurs within approximately $12 \mathrm{~h}$ before parturition (Nara \& First, 1981a, b) and soon after the pre-partum surge in relaxin levels (Sherwood, Wilson, Edgerton \& Chang, 1978). The data presented in this report indicate that the onset of lactation is not dependent on the pre-partum presence of relaxin. Like the controls, gilts with no apparent relaxin in their blood showed onset of lactation within $12 \mathrm{~h}$ pre partum.

In conclusion, the results presented in this report provide evidence in favour of the view that (1) relaxin facilitates expulsion of the fetuses at birth and contributes to the high incidence of live piglets, and (2) onset of lactation is not prevented by an absence of relaxin in blood.

Research supported by the College of Agricultural and Life Sciences, University of Wisconsin-Madison, Wisconsin 53706, ARS CSRS Grant 616-15-152, Grant 630-0505B from the Ford Foundation, a grant from the National Pork Producers Council (B.S.N. and N.L.F.); NIH Grant HD-08700 from USPHS (O.D.S. and J.E.R.), and Research Career Development Award 1-K04-HD-00019 (O.D.S.). Department of Meat and Animal Science paper number 789.

\section{References}

Dziuk, P.J., Phillips, T.N. \& Graber, J.W. (1964) Halothane closed-circuit anesthesia in the pig. $A m$.J. vet. Res. 25, 1773-1775.

Friend, D.W., Cunningham, H.M. \& Nicholson, J.W.G. (1962) The duration of farrowing in relation to the reproductive performance of Yorkshire sows. Can.J. comp. Med. vet. Sci. 26, 127-130.

Kertiles, L.P. \& Anderson, L.L. (1979) Effect of relaxin on cervical dilatation, parturition and lactation in the pig. Biol. Reprod. 21, 57-68.

MacDonald, M.A., Holmes, D.E. \& Moxley, J.E. (1963) Some factors influencing the losses of pigs prior to weaning. Can. J. comp. Med. vet. Sci. 27, 237-240.

Nara, B.S. \& First, N.L. (1981a) Effect of indomethacin on dexamethasone-induced parturition in swine. $J$. Anim. Sci. 52, 788-793.

Nara, B.S. \& First, N.L. (1981b) Effect of indomethacin and prostaglandin $\mathrm{F}_{2} \alpha$ on parturition in swine. $J$. Anim. Sci. 52, 1360-1370.

Nara, B.S., Darmadja, D. \& First, N.L. (1981) Effect of removal of follicles, corpora lutea or ovaries on maintenance of pregnancy in swine. J. Anim. Sci. 52, $794-801$.
Randall, G.C.B. (1972) Observations on parturition in the sow. II. Factors influencing stillbirths and perinatal mortality. Vet. Rec. 90, 183-186.

Rodbard, D. \& Lewald, J.E. (1970) Computer analysis of radioligand and radioimmunoassay data. Acta endocr., Copenh., Suppl. 147, 79-103.

Sherwood, O.D. \& O'Byrne, E.M. (1974) Purification and characterization of porcine relaxin. Arch. Biochem. Biophys. 160, 185-196.

Sherwood, O.D., Rosentreter, K.R. \& Birkhimer, M.L. (1975) Development of a radioimmunoassay for porcine relaxin using ${ }^{125} \mathrm{I}$-labelled polytyrosyl-relaxin. Endocrinology 96, 1106-1113.

Sherwood, O.D., Wilson, M.E., Edgerton, L.A. \& Chang, C.C. (1978) Serum relaxin concentrations in pigs with parturition delayed by progesterone administration. Endocrinology 102, 471-475.

Sherwood, O.D., Crnekovic, V.E., Gordon, W.L. \& Rutherford, J.E. (1980) Radioimmunoassay of relaxin throughout pregnancy and during parturition in the rat. Endocrinology 107, 691-698.

Sherwood, O.D., Nara, B.S., Welk, F.A., First, N.L. \& Rutherford, J.E. (1981) Relaxin levels in the maternal 
plasma of pigs before, during and after parturition and before, during and after suckling. Biol. Reprod. 25, 65-71.

Sprecher, D.J., Leman, A.D., Dziuk, P.J., Cropper, M. \& DeDecker, M. (1974) Causes and control of swine stillbirths. J. Am. vet. med. Ass. 165, 698-701.

Staigmiller, R.B., Short, R.E., Bellows, R.A. \& Carr, J.B. (1979) Effect of nutrition on response to exogenous FSH in beef cattle. J. Anim. Sci. 48, 1182-1190.
Steele, R.G.D. \& Torrie, J.H. (1960) Transformations. In Principles and Procedures of Statistics, pp. 156-158. McGraw-Hill, New York.

Zarrow, M.X., Neher, G.M., Sikes, D., Brennan, D.M. \& Bullard, J.F. (1956) Dilatation of the uterine cervix of the sow following treatment with relaxin. Am. J. Obstet. Gynec. 72, 260-264.

Received 22 February 1982 